\title{
The Impact of Top Management Support, Training, and Perceived Usefulness on Technology Acceptance
}

\author{
Yaser Hasan Al-Mamary \\ Alina Shamsuddin \\ Universiti Tun Hussein Onn Malaysia, Faculty of Technology Management and Business, 86400 Malaysia \\ yaser_almamary@yahoo.com/alina@uthm.edu.my
}

\section{Doi:10.5901/mjss.2015.v6n6s4p11}

\begin{abstract}
The purpose of this study is to investigate the impact of top management support, training, and perceived usefulness on the acceptance of technology in Yemeni organizations. The questionnaire used to collect the data. The questionnaire was prepared on the basis of review of literature. 250 completed questionnaires were received from the telecommunication companies in Yemen. Data were obtained through 4 companies. The responses were collected on seven point liker type scale ranging from strongly disagree to strongly agree. This study analyzed the data two times first with Pearson correlation (SPSS), second by using structural equation modeling techniques (AMOS Graphics), then compare the findings. Based on correlation techniques this study found that there are significant relationship between top management support, training, and perceived usefulness with acceptance of the technology. In other hands, based on SEM techniques this study found that there is significant relationship between perceived usefulness and acceptance of the technology.
\end{abstract}

Keywords: Top Management Support, Training, Perceived Usefulness, Acceptance of Technology, Yemeni Organizations.

\section{Introduction}

Researchers especially in Yemen are more interested to study about technology adoption due to global development in various fields. The adoption of technology in organizations directly contribute to improve the technological capability of a company; which contribute towards the organizational performance (Al-Mamary et al, 2015a). Overall, the technology in organizations cannot improve organizational performance if they aren't used. Unfortunately, resistance to end-user systems by managers and professionals is a widespread problem. To better predict, explain, and increase user acceptance, need to better understand why people accept or reject the computers and the technology (Davis et al,1989). The majority of Arab countries in Middle East and underdeveloped countries especially in Yemen are still dealing with issues in acceptance of the technologies (Al-Mamary et al, 2015b). The acceptance of technologies in companies is much depending on technology factors, project and organizational factors, user and social factors, and task factors (Petter et al,2013). However in reality these factors are much neglected by organizations especially among small companies (Al-Mamary et al,2014).

Many studies supported that TMS, training, and perceived usefulness have positive effect on technology acceptance.

Al Haderi (2014) supported that top management has positive effects on technology acceptance and without its support the organization will face problems in developing, planning and usage of IT. According to Igbaria et al (1997) TMS create a more conducive environment for IS success. Therefore, TMS is associated with greater system success and lack of it is considered a critical barrier to the effective utilization of IT. In addition, Al-Mamary et al (2014) supported that top management support and training are factors affecting on acceptance of technology in Yemeni companies.

Moreover, Yaghoubi \& Bahmani (2010) supported that perceived usefulness have a positive effect on acceptance of the technology.

This study is designed to investigate the impact of top management support, training, and perceived usefulness with acceptance of the technology. Based on the overview of the study, three research objectives are formulated that are described as follows:

RO1. To investigate the impact of top management support in acceptance of the technology . RO2. To investigate the impact of training in acceptance of the technology .

RO3. To investigate the impact of perceived usefulness in acceptance of the technology. 


\section{Conceptual Model}

Based on the previous researches which supported that there are positive relationship between top management support, training, and perceived usefulness with acceptance or use of the technology, the researchers build the conceptual model as follow:

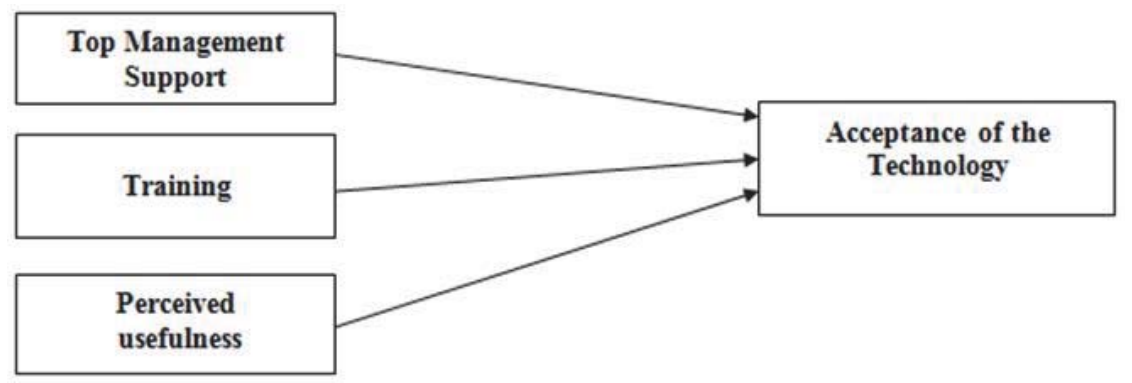

Figure 1: Conceptual Model

This study defines top management support, training, perceived usefulness, and acceptance of the technology as follows:

Top management support is the extent of top management that are understands the importance of the system, and able to ensure sufficient allocation of resources to support and encourages the end-users to use or acceptance of the technology.

Training is the amount of internal and external training that provided to end-users to use the system.

Perceived usefulness is the degree to which end-user believes that using the system enables to accomplish tasks more quickly, and makes the job easier to do.

Acceptance of the technology is the degree to which individual's belief that, he/she happy to use the technology.

\section{Research Hypotheses}

The followings are the research hypotheses that this study seeks to proof .

$\mathrm{H} 1$ - There is a positive relationship between top management support and acceptance of the technology.

$\mathrm{H} 2$ - There is a positive relationship between training and acceptance of the technology.

$\mathrm{H} 3$ - There is a positive relationship between perceived usefulness and acceptance of the technology.

\section{Success Measures}

There are a lot of measures for the variables in the model and these measures differ from one researcher to another. The measures that used in this study are listed in Table 1, and Table 2.

Table 1: Examples of Success Measures - Top Management Support, and Training

\begin{tabular}{|l|l|}
\hline TMS / Igbaria et al. (1997) & Training / Igbaria et al. (1997) \\
\hline 1. Aware of the benefits that can be achieved with using the system. & 1. Offers training to use the system . \\
\hline 2. Supports and encourages the use of the system. & 2. Offers internal training . \\
\hline 3. Provides most of the necessary help and resources. & 3. Offers external training . \\
\hline 4. Management is keen to see people happy with using the system. & 4. Training to use Microsoft applications. \\
\hline 5. Provides good access to hardware resources. & 5. Training to use application packages. \\
\hline 6. Provides good access to various types of software & 6. Training to use operation systems. \\
\hline
\end{tabular}


Table 2: Examples of Success Measures - Perceived Usefulness, and Acceptance of The Technology

\begin{tabular}{|l|l|}
\hline Perceived usefulness / Davis (1989) & Acceptance or Use of The Technology / Seddon \& Kiew (1996) \& Palvia (1996) \\
\hline 1. Accomplish the tasks more quickly. & 1. Meets our needs. \\
\hline 2. Improves performance. & 2. Efficiency. \\
\hline 3. Increases productivity . & 3. Effectiveness. \\
\hline 4. Enhance effectiveness & 4. Successful. \\
\hline 5. Makes it easier to do my job. & 5. Meets our expectations. \\
\hline 6. Overall, the system useful . & 6. Overall, we accepted the system. \\
\hline
\end{tabular}

\section{Instrument and Data Analysis Method}

This study used questionnaire to collect the data. The questionnaire developed based on the literature review. The questionnaires are divided into 5 parts with a total of 31 questions.

Data was analyzed quantitatively using the appropriate descriptive analysis for the distribution of population and demographic while validate to model using structural equation modeling techniques. In addition, test the relationship between top management support, training, and perceived usefulness with acceptance of the technology by using Pearson correlation.

\section{Reliability}

Cronbach's Coefficient Alpha method used to measure the reliability between various questionnaires items. Table 3 shows the reliability for each variable.

Table 3: Testing Reliability Result

\begin{tabular}{|c|c|c|}
\hline Items & Cronbach's Alpha & N of Items \\
\hline TMS & 0.916 & 6 \\
\hline T & 0.857 & 6 \\
\hline US & 0.933 & 6 \\
\hline AOT & 0.946 & 6 \\
\hline
\end{tabular}

\section{Demographic Profiles}

Table 4 shows the following: $40 \%$ of the respondents from Yemen mobile company, $25.6 \%$ from Sabafon company, $31.6 \%$ from MTN company, and $2.4 \%$ from Y company. $37.2 \%$ of the respondents from information system department, $43.6 \%$ from customer service department, $10 \%$ from accounting and finance department, $5.6 \%$ from human resource department, and $3.6 \%$ from marketing and sales department. $84 \%$ of the respondents are male, and $16 \%$ are female. $49.6 \%$ of the age of the respondents less than $30,45.6 \%$ between 30 and $40,4.8 \%$ between 40 and $50.0 .4 \%$ of the respondents have high school, $4.8 \%$ have diploma, $88.8 \%$ have bachelor degree, $5.6 \%$ have master degree, and $0.4 \%$ have $\mathrm{PhD}$. $35.2 \%$ of the respondents are administrative staff, $21.6 \%$ are technical support staff, $5.6 \%$ are heads of departments, $2.4 \%$ are managers, and $35.2 \%$ from another position. $18 \%$ of the respondents working experience less than 2 years, $24 \%$ working experience between 2 and 4 years, 19.6\% working experience between 4 and 6 years, 16\% working experience between 6 and 8 years, and 22.4\% working experience above 8 years.

Table 4: Demographic Profiles

\begin{tabular}{|l|l|c|c|}
\hline & & Frequency & Percent \\
\hline \multirow{5}{*}{ Company } & Yemen Mobile & 101 & 40.0 \\
\cline { 2 - 4 } & Sabafon & 64 & 25.6 \\
\cline { 2 - 4 } & MTN & 79 & 31.6 \\
\cline { 2 - 4 } & Y & 6 & 2.4 \\
\hline \multirow{5}{*}{ Department } & Information Systems/ IT & 93 & 37.2 \\
\cline { 2 - 4 } & Customers Service & 109 & 43.6 \\
\cline { 2 - 4 } & Accounting and Finance & 25 & 10.0 \\
\hline
\end{tabular}




\begin{tabular}{|c|c|c|c|}
\hline & Human Resource & 14 & 5.6 \\
\hline & Marketing and Sales & 9 & 3.6 \\
\hline \multirow[t]{2}{*}{ Gender } & Male & 210 & 84.0 \\
\hline & Female & 40 & 16.0 \\
\hline \multirow{3}{*}{ Age Group } & Less than 30 & 124 & 49.6 \\
\hline & 30 less than 40 & 114 & 45.6 \\
\hline & 40 less than 50 & 12 & 4.8 \\
\hline \multirow{5}{*}{ Education } & High School & 1 & 0.4 \\
\hline & Diploma & 12 & 4.8 \\
\hline & Bachelor & 222 & 88.8 \\
\hline & Master & 14 & 5.6 \\
\hline & PhD & 1 & 0.4 \\
\hline \multirow{5}{*}{ Position } & Administration Staff & 88 & 35.2 \\
\hline & Technical Support Staff & 54 & 21.6 \\
\hline & Head of Department & 14 & 5.6 \\
\hline & Manager & 6 & 2.4 \\
\hline & Others & 88 & 35.2 \\
\hline \multirow{5}{*}{ Working Experience } & Less than 2 & 45 & 18.0 \\
\hline & 2 - less than 4 & 60 & 24.0 \\
\hline & 4 - less than 6 & 49 & 19.6 \\
\hline & 6 - less than 8 & 40 & 16.0 \\
\hline & Above 8 & 56 & 22.4 \\
\hline
\end{tabular}

\section{Summary of The Findings (Correlation Analysis)}

Table 5 shows the correlation between TMS, training, and perceived usefulness with acceptance of the technology.

Table 5: Correlations

\begin{tabular}{|c|c|}
\hline & AOT \\
\hline TMS Pearson Correlation & $0.313^{\star *}$ \\
Sig. (2-tailed) & 0.000 \\
N & 250 \\
\hline T Pearson Correlation & $0.217^{* *}$ \\
Sig. (2-tailed) & 0.001 \\
N & 250 \\
\hline PU Pearson Correlation & $0.438^{\star *}$ \\
Sig. (2-tailed) & 0.000 \\
N & 250 \\
\hline
\end{tabular}

** Correlation is significant at the 0.01 level (2-tailed).

${ }^{*}$ Correlation is significant at the 0.05 level (2-tailed).

Based on Table 5, it can be deduced that there are a positive correlated relationship between top management support, training, and perceived usefulness with acceptance of the technology. And Table 6 shows the results of the hypothesis in the findings.

Table 6: Summary of the Findings Based on Correlation Analysis

\begin{tabular}{|l|l|}
\hline Research Hypothesis & Results \\
\hline H1 - There is a positive relationship between top management support and acceptance of the technology. & Supported \\
\hline H2 - There is a positive relationship between training and acceptance of the technology. & Supported \\
\hline H3 - There is a positive relationship between perceived usefulness and acceptance of the technology. & Supported \\
\hline
\end{tabular}

\section{Level of Acceptance (Goodness-of-Fit indexes)}

The recommended level of acceptance are presented in Table 7. 
Table 7: Level of Acceptance (Goodness-of-Fit indexes)

\begin{tabular}{|l|}
\hline Level of Acceptance / Adopted \\
\hline chisq/df $<5.0$ / Awang (2012) ; Al-Mamary \& Shamsuddin (2015c) \\
\hline NFI >= 0.9 means satisfactory / Awang (2012) ; Al-Mamary \& Shamsuddin (2015c) \\
Fit 0.8 < NFI< 0.9 means acceptable fit / Forza \&Filippini (1998) ; Al-Mamary \& Shamsuddin (2015c) \\
\hline CFI >= 0.9 means satisfactory fit / Awang (2012); Hair et al (2010); Al-Mamary \& Shamsuddin (2015c) \\
\hline GFI >= 0.9 means satisfactory fit/ [14]; [16] 0.8< GFI 0.9 means acceptable fit / \\
Greenspoon and Saklofske (1998); Forza and Filippini (1998); Al-Mamary \& Shamsuddin (2015c) \\
\hline TLI >= 0.9 means satisfactory fit / Forza and Filippini (1998); Awang (2012); Al-Mamary \& Shamsuddin (2015c) \\
\hline RMSEA < 0.08 / Awang (2012) ; Al-Mamary \& Shamsuddin (2015c) \\
\hline
\end{tabular}

\section{Structural Model}

The structural model did not fit well .The CFI, GFI, TLI, and RMSEA not achieved the required level.

Table 8: Goodness of Fit indexes for the Initially Proposed Structural Model

\begin{tabular}{|c|c|}
\hline Index Value & Comments \\
\hline chisq/df $=4.263$ & The required level is achieved \\
\hline $\mathrm{NFI}=0.805$ & The required level is achieved \\
\hline $\mathrm{CFI}=0.842$ & The required level is not achieved \\
\hline $\mathrm{GFI}=0.715$ & The required level is not achieved \\
\hline $\mathrm{TLI}=0.823$ & The required level is not achieved \\
\hline $\mathrm{RMSEA}=0.114$ & The required level is not achieved \\
\hline
\end{tabular}

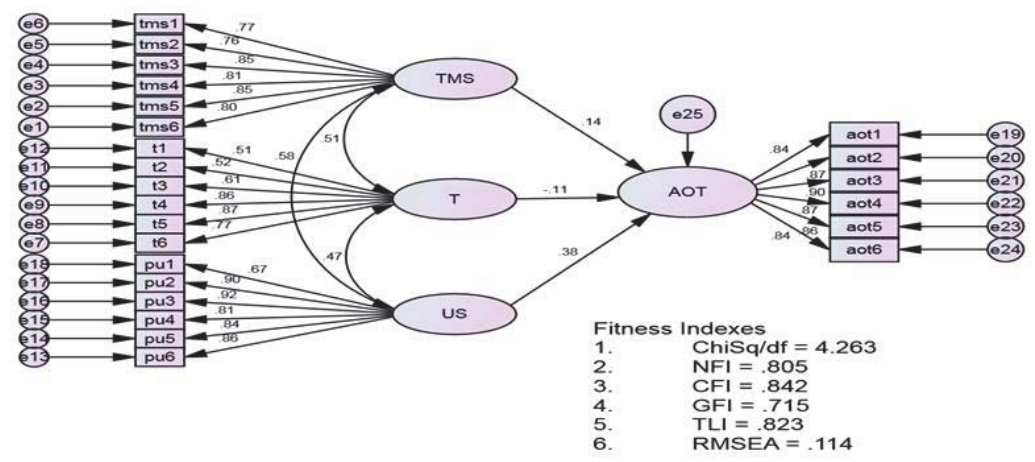

Figure 2: Initially structural model

After dropping the problematic items, the structural model was re-run. Final structural model is depicted in Figure 3. 


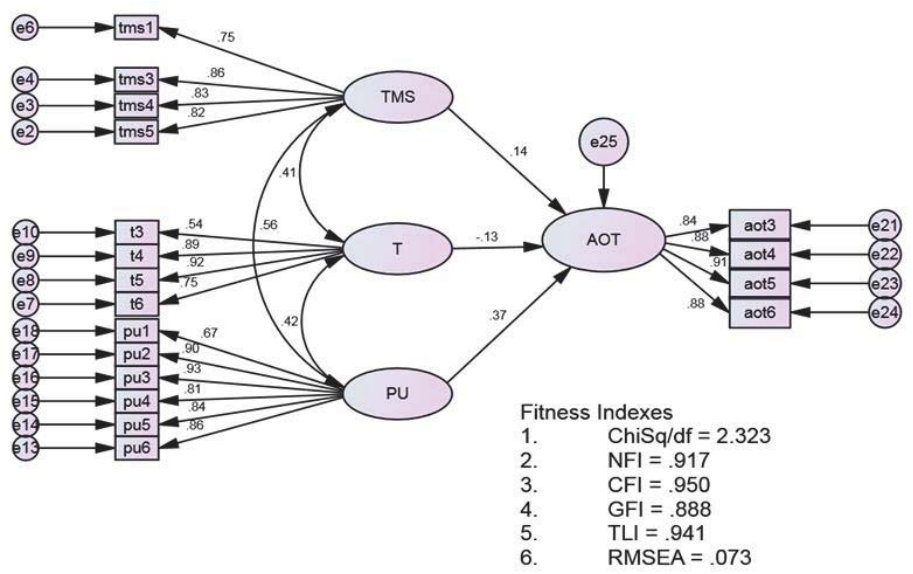

Figure 3: Revised structural model

Table 9: Goodness of Fit indexes for Revised Structural Model

\begin{tabular}{|c|c|}
\hline Index Value & Comments \\
\hline chisq/df $=2.323$ & The required level is achieved \\
\hline $\mathrm{NFI}=0.917$ & The required level is achieved \\
\hline $\mathrm{CFI}=0.950$ & The required level is achieved \\
\hline $\mathrm{GFI}=0.888$ & The required level is achieved \\
\hline $\mathrm{TLI}=0.941$ & The required level is achieved \\
\hline $\mathrm{RMSEA}=0.073$ & The required level is achieved \\
\hline
\end{tabular}

\section{Summary of Research Hypotheses}

Table 10 shows the results of the hypotheses based on structural model. If compare between the hypotheses in Table 6 based on Pearson correlation, found that the results are differ based on the used technique.

Table 10: Summary of Hypotheses Testing

\begin{tabular}{|c|c|c|}
\hline Path & Critical Ratios & p-value \\
\hline TMS-->AOT & 1.708 & 0.088 \# Rejected \\
\hline T-->AOT & -1.742 & 0.081 \# Rejected \\
\hline PU-->AOT & 4.534 & *** Supported \\
\hline
\end{tabular}

Note: * $p<0.05 ;{ }^{* \star} p<0.01 ;{ }^{* \star *} \mathrm{P}<0.001 ; \mathrm{TMS}=$ Top Management Support; T= Training ;PU= Perceived Usefulness; AOT= Acceptance of the Technology.

\section{Conclusion}

This study presents the factors affecting the acceptance of technology in Yemeni organizations. It aimed to investigate the effects of top management support, training, and perceived usefulness on accept of the technology. A total of 250 respondents from a telecommunication company located in Sana'a (Yemen) participated in this study by completing a survey questionnaire. AMOS Graphics was used to testing the statistical relationship between the constructs presented in the proposed model. In addition, this study used Pearson correlation to measure the correlation between the constructs. This study mention that the results are differ based on the used technique. 


\section{Acknowledgments}

The authors would like to thank the ORRIC, UTHM for the university's cooperation and financial support under Vot Number 1429.

\section{References}

Al-Mamary, Y.H., Shamsuddin, A. \& Abdul Hamid, N.A. (2015a) Enhancing Technological Capability of Telecommunications Sector in Yemen : A Technology Adoption Approach, Mediterranean Journal of Social Sciences, 6(4).

Al-Mamary, Y.H., Shamsuddin, A. \& Aziati, N. (2015b). Investigating the key factors influencing on Management Information Systems adoption among Telecommunication Companies in Yemen: The Conceptual Framework Development, International Journal of Energy, Information and Communications. 6(1).

Al-Mamary, Y.H., \& Shamsuddin, A. (2015c) Testing of The Technology Acceptance Model in Context of Yemen, Mediterranean Journal of Social Sciences, 6(4).

Al-Mamary, Y.H., \& Shamsuddin,A., \& Nor Aziati, A.H. (2014) Key factors enhancing acceptance of management information systems in Yemeni companies, Journal of Business and Management Research, Volume. 5, pp. 108-111.

Awang, Z. 2012. Structural equation modeling using AMOS graphic. Penerbit Universiti Teknologi MARA.

Davis, F. D., Bagozzi, R. P., \& Warshaw, P. R. (1989). User acceptance of computer technology: a comparison of two theoretical models. Management science, 35(8), 982-1003.

Davis, F.D. (1989). Perceived usefulness, Perceived ease of use, and user acceptance of information technology. MIS Quarterly, 13, pp.319-340.

Forza \& Filippini, R. (1998) Tqm impact on quality conformance and customer satisfaction: a causal model.

Greenspoon \& Saklofske, D.H. (1998) Confirmatory factor analysis of the multidimensional students life satisfaction scale. Personality and Individual Differences, 25(5), pp. 965-971.

Hair, J., Anderson, R., Tatham, R. \& Black,W. (2010) Multivariate Data Analysis 7th edition Prentice Hall.

Igbaria, M., \& Zinatelli,N., \& Zinatelli,P., \& Cavaye, A. L.M.(1997) Personal Computing Acceptance Factors in Small Firms: A SEM, MIS Quarterly.

Petter, S., DeLone, W., \& McLean, E. R. (2013). Information Systems Success: The Quest for the Independent Variables. Journal of Management Information Systems, Vol. 29, No. 4, pp. 7-61.

Sami Mohamed Al Haderi (2014) The Influences of Government Support in Accepting the Information Technology in Public Organization Culture ,International Journal of Business and Social Science, 5(5).pp.118-124.

Seddon, P., \& Kiew, M. Y. (1996). A partial test and development of DeLone and McLean's model of IS success. Australasian Journal of Information Systems, 4(1).

Yaghoubi, N. M. \& Ebrahim bahmani (2010). Factors Affecting the Adoption of Online Banking-An Integration of Technology Acceptance Model and Theory of Planned Behavior. International Journal of Business and Management, 5(9), p159.

Palvia, P. C. (1996). A model and instrument for measuring small business user satisfaction with information technology. Information \& Management, 31(3), 151-163. 